\title{
KETERLAKSANAAN KURIKULUM 2013 MATA PELAJARAN PENJASORKES DI SEKOLAH DASAR SE-KECAMATAN MELIAU
}

\author{
Widia Tri Eksanurianto ${ }^{1}$,Eka Supriatna ${ }^{2}$, Fitriana Puspa Hidasari', \\ ${ }^{1}$ Mahasiswa Program Studi Pendidikan Jasmani FKIP Untan Pontianak. \\ ${ }^{2,3}$ Dosen Program Studi Pendidikan Jasmani FKIP Untan Pontianak \\ Email: ${ }^{1}$ widiatrieksanurianto@gmail.com, ${ }^{2}$ eka.supriatna@ fkip.untan.ac.id, \\ ${ }^{3}$ fitriana.puspa@fkip.untan.ac.id
}

\begin{abstract}
Public Elementary Schools in Meliau District have not been able to implement the 2013 curriculum, due to incomplete supporting facilities to implement the 2013 curriculum. The aim of this research is to achieve know the implementation of the 2013 curriculum for Physical Education subjects in Elementary Schools in Meliau District. This research is a quantitative research with descriptive research type, with survey methods and data collection techniques using a questionnaire. The subjects in this study were 28 teachers of PJOK SD in Meliau District. To analyze the data used descriptive statistics with percentages. Based on the results of the study, it is known that the implementation of the 2013 curriculum for physical education and health services in elementary schools throughout Meliau District in implementing the 2013 curriculum is in the very high category of $0 \%$, the high category is $7.1 \%$, the moderate category is $67.9 \%$, the low category is $21.4 \%$ and very low category of $3.6 \%$. Based on these results it can be concluded that the implementation of the 2013 curriculum for Physical Education subjects in Elementary Schools in Meliau District is mostly in the medium category.
\end{abstract}

Keywords: Elementary schools, implementation of PJOK teachers, Implementation of the 2013 curriculum

\begin{abstract}
Abstrak: Sekolah Dasar Negeri di Kabupaten Meliau belum mampu melaksanakan kurikulum 2013, dikarenakan fasilitas pendukung yang belum lengkap untuk melaksanakan kurikulum 2013. Tujuan dari penelitian ini adalah untuk mengetahui implementasi kurikulum 2013 mata pelajaran Pendidikan Jasmani di Sekolah Dasar di Kabupaten Meliau. Penelitian ini merupakan penelitian kuantitatif dengan jenis penelitian deskriptif, dengan metode survei dan teknik pengumpulan data menggunakan kuesioner. Subjek dalam penelitian ini adalah 28 guru SD PJOK di Kabupaten Meliau. Untuk menganalisis data digunakan statistik deskriptif dengan persentase. Berdasarkan hasil penelitian diketahui bahwa implementasi Kurikulum 2013 Pendidikan Jasmani dan Pelayanan Kesehatan di Sekolah Dasar se-Kabupaten Meliau dalam melaksanakan Kurikulum 2013 berada pada kategori sangat tinggi yaitu $0 \%$ kategori tinggi 7,1. \%, kategori sedang 67.9\%, kategori rendah $21.4 \%$ dan kategori sangat rendah 3.6\%. Berdasarkan hasil tersebut dapat disimpulkan bahwa implementasi kurikulum 2013 mata pelajaran Pendidikan Jasmani di Sekolah Dasar di Kabupaten Meliau sebagian besar berada pada kategori sedang.
\end{abstract}

Kata Kunci: Sekolah Dasar, Penerapan Guru PJOK, Penerapan Kurikulum 2013 


\section{Jurnal Pendidikan Jasmani Kesehatan dan Rekreasi (Penjaskesrek) \\ Volume 8, Nomor 1, Januari 2021}

$\mathrm{K}^{\mathrm{u}}$ urikulum merupakan salah satu alat yang digunakan untuk mencapai suatu tujuan pendidikan, dan merupakan pedoman bagi pendidik dalam melaksanakan pembelajaran pada semua jenis dan jenjang pendidikan. Sejarah kurikulum di Indonesia sudah melalui perjalanan panjang, sejarah mencatat perubahan tersebut mulai tahun 1947 atau disebut Rentjana Pelajaran 1947, 1952 disebut Rentjana Pelajaran Terurai 1952, 1964 disebut Rentjana Pendidikan 1964, 1975 disebut dengan satuan pelajaran, ialah rencana pelajaran setiap satuan bahasan, 1984 Kurikulum ini juga sering disebut "Kurikulum 1975 yang telah disempurnakan, tahun 1994 pemerintah kembali memperbarui kurikulum sebagai upaya menggabungkan kurikulum yang sebelumnya,

Kurikulum 1975 dan 1984, Pada tahun 2004 dilakukan Kurikulum Berbasis Kompetensi (KBK) sebagai pengganti dari Kurikulum 1994, 2006 Kurikulum ini hampir menyerupai dengan Kurikulum 2004, perbedaan terletak pada kewenangan dalam penyusunannya, yaitu mengacu pada jiwa dari desentralisasi sistem pendidikan, dan yang paling anyar adalah kurikulum 2013, Kurikulum ini adalah pengganti kurikulum KTSP. Kurikulum 2013 memiliki tiga aspek penilaian, yaitu aspek kognitif, aspek psikomotor, dan aspek afektif.

Kurikulum 2013 yaitu lanjutan sebuah penyempurnaan dari kurikulum berbasis kopetensi (KBK) yang telah dimulai sejak tahun 2004 dengan mencakup kopetensi sikap, pengetahuan, dan keterampilan secara terpadu, yang dapat membekali peserta didik dengan berbagai kemampuan yang sesuai dengan tuntutan zaman,guna menjawab tantangan arus globalisasi berkonstribusi pada pembangunan masyarakat dan kesejahteraan sosial, lentur dan adaptif terhadap berbagai perubahan. Menurut Setiadi (2016: 168) ''kurikulum yaitu acuan bagi instansi pendidikan dalam menjalankan proses pendidikan untuk mencapai tujuan tertentu'.

Di kabupaten Sanggau, tepatnya di kecamatan Meliau telah banyak berdiri infrastruktur pendidikan untuk menunjang kemajuan suatu kompetensi dalam pendidikan. Berdasarkan data Dapodik dasmen 2018 di Kecamatan Meliau telah berdiri 69 sekolah yang terdiri dari 51 sekolah dasar, 14 sekolah menengah pertama serta 4 sekolah menengah atas. Berdasarkan data yang diperoleh melalui observasi dilapangan penerapan kurikulum 2013 di Kecamatan Meliau tidak berjalan serentak, sehingga setiap sekolah menerapkan kurikulum yang berbeda-beda.

Dari hasil data obeservasi dilapangan terdapat kategori sekolah yang menerapkan kurikulum KTSP dan K-1 sebagai berikut: SDN 25 Nek Bindang kelas 3 dan 6 menggunakan KTSP, sedangkan kelas 1,2,4, dan 5 menggunakan K-13, SDN 35 
Sengkuang Daok kelas 2, 3, dan 5 menggunakan KTSP, kelas 1 dan 4 menggunakan K-13, SDN 05 Sungai dekan kelas1 hingga kelas 6 sudah menggunakan K13, SDN Tapang Sedendang kelas 3 dan 6

menggunakan KTSP, kelas 1, 2, 4, dan 5 menggunakan K-13, SDN 34 Batu Laut kelas 3 dan 6 menggunakan KTSP, kelas 1, 2, 4 dan 5 menggunakan K-13, SDN 46 Suak Pram kelas 3 dan 6 menggunakan KTSP, kelas 1, 2, 4 dan 5 menggunakan K-13.

Dari data yang telah dipaparkan di atas, pelaksanaan kurikulum 2013 di Kecamatan Meliau belum merata dilaksanakan pada sekolah tingkat dasar. Hal ini menimbulkan permasalahan baru berkenaan adanya dua kurikulum yang berbeda yang diterapkan oleh sekolah. Merujuk pada data diatas, peneliti tertarik untuk mengungkap efektifitas pelaksanaan kurikulum 2013 karena masih banyak guru yang belum memahami kurikulum 2013 serta tidak semua guru melaksanakan pelatihan tentang kurikulum 2013 sehingga pelaksanaan kurikulum 2013 belum berjalan dengan serentak di kecamatan meliau.

Pengertian Kurikulum dan perkembangan Kurikulum

Kurikulum yaitu suatu program pendidikan yang memuat berbagai bahan ajar dan pengalaman belajar yang diprogramkan, direncanakan dan dirancangkan secara sistematik atas dasar norma-norma yang berlaku yang dijadikan pedoman dalam proses pembelajaran bagi guru dan siswa agar mencapai tujuan pendidikan (Dakir, 2010: 3) Ada sejumlah ahli teori kurikulum yang berpendapat bahwa kurikulum merupakan suatu sistem, memiliki komponen-komponen yang saling berkaitan antara satu dengan yang lainnya.

Kurikulum tidak hanya meliputi bahan pelajaran, tetapi juga meliputi seluruh kehidupan dalam kelas, termasuk didalamnya hubungan sosial anatar guru dan murid, metode mengajar, dan cara mengevaluasi. Undang-undang nomor 20 tahun 2003 dan peraturan pemerintah nomor 19 tahun 2005 menetapkan pengertian kurikulum sebagai "seperangkat rencana dan pengaturan mengenai tujuan, isi dan bahan pelajaran serta cara yang digunakan sebagai panduan pelaksanaan kegiatan pembelajaran untuk mencapai sebuah tujuan pendidikan tertentu". Menurut zainal arifin (2012:2) kurikulum adalah soal pilihan(curriculum is amatter choice) pilihan itu biasanya dilakuakan oleh"orang-orang berkuasa" (pemerintah). Menurut Roni (2018: 29) 'DDari penjelasan diatas maka dapat disimpulakan

bahwa kurikulum 2013 merupakan seperangkat rencana dan pengaturan mengenai tujuan, isi dan bahan pelajaran yang digunakan sebagai pedoman dalam kegiatan pembelajaran. 


\section{Pengertian kurikulum 2013}

Kurikulum 2013 merupakan tindak lanjut dari kurikulum berbasis kompetensi (KBK) yang pernah diujicobakan pada tahun 2004. KBK atau (kopentcy Based Curriculum) dijadikan acuan dan pedoman bagi pelaksanaan pendidikan untuk mengembangkan berbagai ranah pendidikan (pengetahuan, keterampilan dan sikap) dalam seluruh jenjang dan jalur pendidikan, khususnya pada jalur pendidikan sekolah. Mulyasa ( 2017 : 66 ).

\section{Tujuan Kurikulum 2013}

Tujuan dilakukan perubahan kurikulum yaitu untuk "Melanjutkan pengembangan kurikulum berbasis kompetensi yang telah dilakukan sejak tahun 2004 dengan mencakup kompetensi sikap, pengetahuan, dan keterampilan secara terpadu" (Mulyasa, 2013: 65).

Hal terpenting, bertujuan untuk memotivasi siswa, agar mampu menjadi lebih baik dalam melakukan eksplorasi, menanya,memahami, dan menjelaskan (mempersentasikan), apa yang mereka peroleh atau mereka ketahui setelah menerima materi dari pendidik. Adapun objek yang menjadi pembelajaran dalam penataan dan penyempurnaan kurikulum 2013 menekankan pada fenomena alam, sosial, seni dan budaya.

Kementerian pendidikan dan kebudayaan (kemendikbud) menetapkan para guru calon peserta pelatihan implementasi kurikulum 2013. Para guru tersebut mendapatkan pelatihan supaya siap melaksanakan kurikulum 2013 sehingga tidak terjadi kesulitan saat mengajar. Guru yang menjadi sasaran utama untuk jenjang Sekolah Dasar (SD) adalah guru kelas 1, guru kelas 4 dan guru pendidikan jasmani yang sudah terpilih masing-masing sekolah sesuai dengan pelaksanaan tahap pertama (Derap Guru Jawa Tengah, edisi 158/Th. XIII/Maret 2013).

\section{Kelebihan Kurikulum 2013}

Dalam pembelajaran berdasarkan kurikulum 2013 menggunakan metode tematik, dimana materi pembelajaran disesuaikan dengan tema. Dalam satu tahun ajaran terdapat 4 tema yang didalamnya terdapat 4 sub temadan di tiap sub semater dapat 6 pembelajaran. Dari semua tema yang ditentukan, semuanya memiliki satu tujuanya itu membentuk karakter anak bangsa. Proses pembelajaran untuk jenjang Sekolah Dasar (SD) atau yang sederajat menggunakan pendekatan-pendekatan tematik. Model pembelajaran tematik terpadu (PTP) atau integrated thematic intruction (ITI), dikembangkan pertama kali tahun 1970an. PTP diyakini sebagai salah satu model-model pembelajaran yang efektif, karena mampu mewadahi dan menyentuh secara terpadu dimensi emosi, fisik, dan akademik didalam kelas atau dilingkungan sekolah. 
Dalam buku Materi Pelatihan Guru Implementasi Kurikulum 2013 (195-200). Model pembelajaran tematik integratif adalah model pembelajaran melalui beberapa tahap yaitu pertama guru harus mengacu pada tema sebagai pemersatu berbagai mata pelajaran untuk satu tahun. Kedua guru melakukan analisis standar kompetensi lulusan, kompetensi inti, kompetensi dasar dan membuat indikator dengan memperhatikan materi standarisi. Ketiga membuat hubungan antara kompetensi dasar, indikator dengan tema. Keempat membuat KD, indikator. Kelima menyusun silabus tematik dan keenam membuat rancanagan pelaksanaan pembelajaran tematik dengan mengkondisikan pembelajaran yang menggunakan pendekatan scientific.

\section{METODE PENELITIAN}

Metode penelitian yang digunakan dalam melakukan penelitian adalah metode expost facto, dengan bentuk survey, karena penelitian ini sesuai dengan tujuan penelitian yaitu keterlaksanaan guru penjasorkes terhadap kurikulum 2013 sekecamatan meliau. Populasi yang digunakan yaitu sebanyak 28 sekolah dasar dengan melibatkan 28 orang guru Penjasorkes tingkat SD Se-Kecamatan Meliau Kabupaten Sanggau.

Teknik pengumpulan data yang digunakan dalam melakukan penelitian yaitu

(1) tes dan pengukuran, (2) wawancara, (3) observasi, (4) angket, dan (5) dokumentasi. Sehingga alat pengumpulan data yang digunakan berupa kuesioner (angket) tertutup artinya setiap item pernyataa/pertanyaan telah diisi alternative jawaban yang akan diisi oleh responden dengan memberikan tanda centang $(\sqrt{ })$. Kisi-kisi penyusunan angket yang digunakan dengan variabel Keterlaksanaan Guru PJOK Terhadap Kurikulum 2013 dengan mengedepankan faktor-faktor diantaranya Mengetahui tujuan Kurikulum 2013, Meningkatkan pengetahuan, Meningkatkan keterampilan fisik, Mempersiapkan keterampilan proses pembelajaran, Menyiapkan RPP, Mempersiapkan media pembelajaran, Mempersiapkan sarana dan prasarana, Memiliki buku pegangan, dan penilaian, dengan jumlah 36 butir pernyataa/pertanyaan (Nur Asrianti, 2015 : 47). Teknik analisis data yang digunakan yaitu sebagai berikut: (1). Tabulasi dengan kegiatan yang dilakukan memasukan data ke dalam bagan table dan pemberian nilai terhadap item-item yang perlu diberinilai, (2). Penerapan data sesuai dengan pendekatan penelitian dengan metode analisis deskriptif persentase, sebagaimana rumus yang digunakan: 


$$
D p={ }^{\mathrm{n}} \times 100 \%
$$

$N$

Keterangan:

DP : Deskriptif persentase

$\mathrm{n} \quad$ : Jumlah nilai yang

diperoleh $\mathrm{N}$ : jumlah keseluruhan

nilai

Sumber Muhammad Ali (dalam Lestudy, 2012)

\section{HASIL PENELITIAN DAN PEMBAHASAN}

\section{Hasil}

Penilaian dalam penelitian ini terdapat 4 kategori yaitu sangat baik, baik, cukup, dan kurang,. Dimana masing-masing kategori tersebut memiliki rentang dari $0 \%$ sampai $100 \%$. Masing-masing kategori memiliki nilai yang bervariasi yaitu untuk kategori sangat baik 81 sampai 100, untuk kategori baik memiliki rentang nilai dari angka 62 sampai 80 ,

kategori cukup memiliki rentang nilai antara 43 sampai 61,dan kategori kurang memiliki rentang nilai dari 25 sampai 42 .

Berdasarkan penelitian yang dilakukan didapat hasil bahwa keterlaksanaan guru penjasorkes dengan kategori sangat baik sebanyak 4 orang atau $14.3 \%$ kategori baik sebanyak 19 orang atau $67.9 \%$, kategori cukup sebanyak 5 orang atau $17.9 \%$, dan kategori kurang sebanyak 0 orang atau $0 \%$. Setiap kategori yang telah disajikan dapat dilihat pada tabel 1 dan grafik 1 sebagai berikut:

Tabel 1. Persentase Katagori Keterlaksanaan Guru Penjesorkes Di Sekolah Dasar SeKecamatan Meliau Terhadap Kurikulum 2013.

\begin{tabular}{cccc}
\hline No & Kategori & Jumlah Sampel & Persentase \\
\hline 1 & Sangat Baik & 4 orang & $14.3 \%$ \\
\hline 2 & Baik & 19 orang & $67.9 \%$ \\
\hline 3 & Cukup & 5 orang & $17.9 \%$ \\
\hline 4 & Kurang & 0 orang & $0 \%$ \\
\hline
\end{tabular}


Dari tabel 1 diatas lebih jelasnya untuk masing-masing katagori dapat dilihat pada grafik 1 berikut ini.

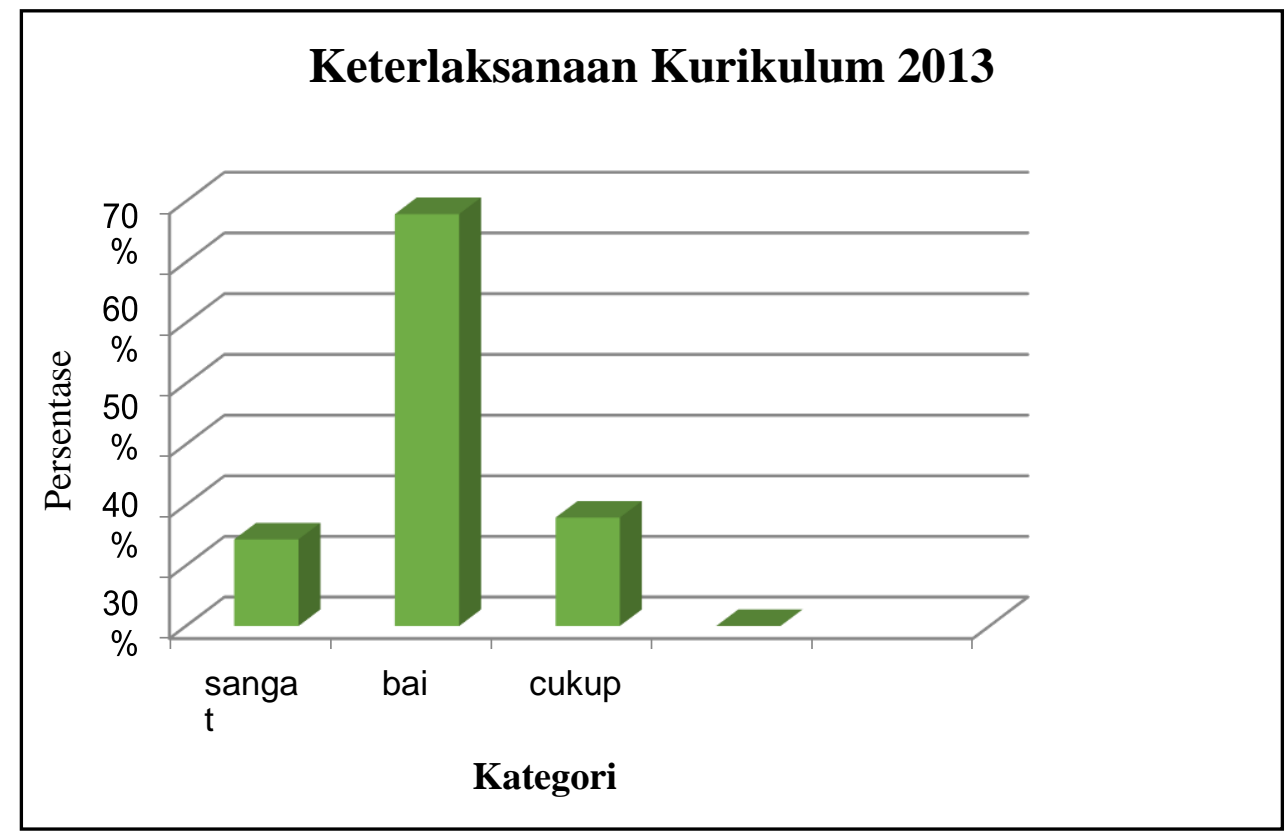

Gambar 1. Persentase Katagori Keterlaksanaan Guru Penjesorkes di Sekolah Dasar SeKecamatan Meliau Terhadap Kurikulum 2013.

Dari grafik 1 diatas, dapat dilihat perbandingannya bahwa keterlaksanaan kurikulum 2013 memiliki kategori sangat baik adalah $14.3 \%$, kategori baik $67.9 \%$, dan kategori cukup $17.9 \%$.

Selanjutnya dalam penelitian keterlaksanaan guru PJOK di Sekolah Dasar se-Kecamatan Meliau terhadap kurikulum 2013 dalam mengimplementasikan kurikulum 2013 didasarkan pada beberapa faktor yaitu mengetahui tujuan kurikulum 2013 meningkatkan pengetahuan, meningkatkan keterampilan fisik, iempersiapkan keterampilan proses pembelajaran, menyiapkan RPP, mempersiapkan media pembelajaran, mempersiapkan sarana dan prasarana, memiliki buku-buku pegangan dan penilaian. Hasil analisis data pada masing-masing faktor tersebut dilihat pada tabel 2 dan grafik 2 berikut ini. 
Jurnal Pendidikan Jasmani Kesehatan dan Rekreasi (Penjaskesrek)

Volume 8, Nomor 1, Januari 2021

Tabel 2. Persentase Faktor Keterlaksanaan Guru Penjesorkes Di Sekolah Dasar SeKecamatan Meliau Terhadap Kurikulum 2013.

\begin{tabular}{|c|c|c|c|c|c|}
\hline No & Faktor & $\begin{array}{l}\text { Jumlah } \\
\text { Butir }\end{array}$ & $\begin{array}{l}\text { Nilai } \\
\text { Ideal }\end{array}$ & $\begin{array}{c}\text { Nilai } \\
\text { Diperoleh }\end{array}$ & $\%$ \\
\hline 1 & Mengetahuai Kurikulum 2013 & 3 & 84 & 70 & 83.33 \\
\hline 2 & $\begin{array}{l}\overline{\bar{D}} \\
\text { Mf́ceningkatkan Pengetahuan } \\
\text { م. }\end{array}$ & 7 & 196 & 149 & 76.02 \\
\hline 3 & Meningkatkan Keterampilan Fisik & 3 & 84 & 51 & 60.71 \\
\hline 4 & $\begin{array}{l}\text { Mempersiapkan Keterampilan } \\
\text { Proses Pembelajaran }\end{array}$ & 4 & 112 & 91 & 81.25 \\
\hline 5 & Menyiapkan RPP & 5 & 140 & 101 & 72.14 \\
\hline 6 & $\begin{array}{l}\text { Mempersiapkan Media } \\
\text { Pembelajaran }\end{array}$ & 2 & 56 & 42 & 75.00 \\
\hline 7 & $\begin{array}{l}\text { Mempersiapkan Sarana Dan } \\
\text { Prasarana }\end{array}$ & 4 & 112 & 73 & 65.18 \\
\hline 8 & Memiliki Buku-Buku Pegangan & 4 & 112 & 77 & 68.75 \\
\hline 9 & Penilaian & 4 & 112 & 100 & 89.29 \\
\hline
\end{tabular}

Dari tabel 2 diatas lebih jelasnya untuk masing-masing katagori dapat dilihat pada grafik 2 berikut ini.

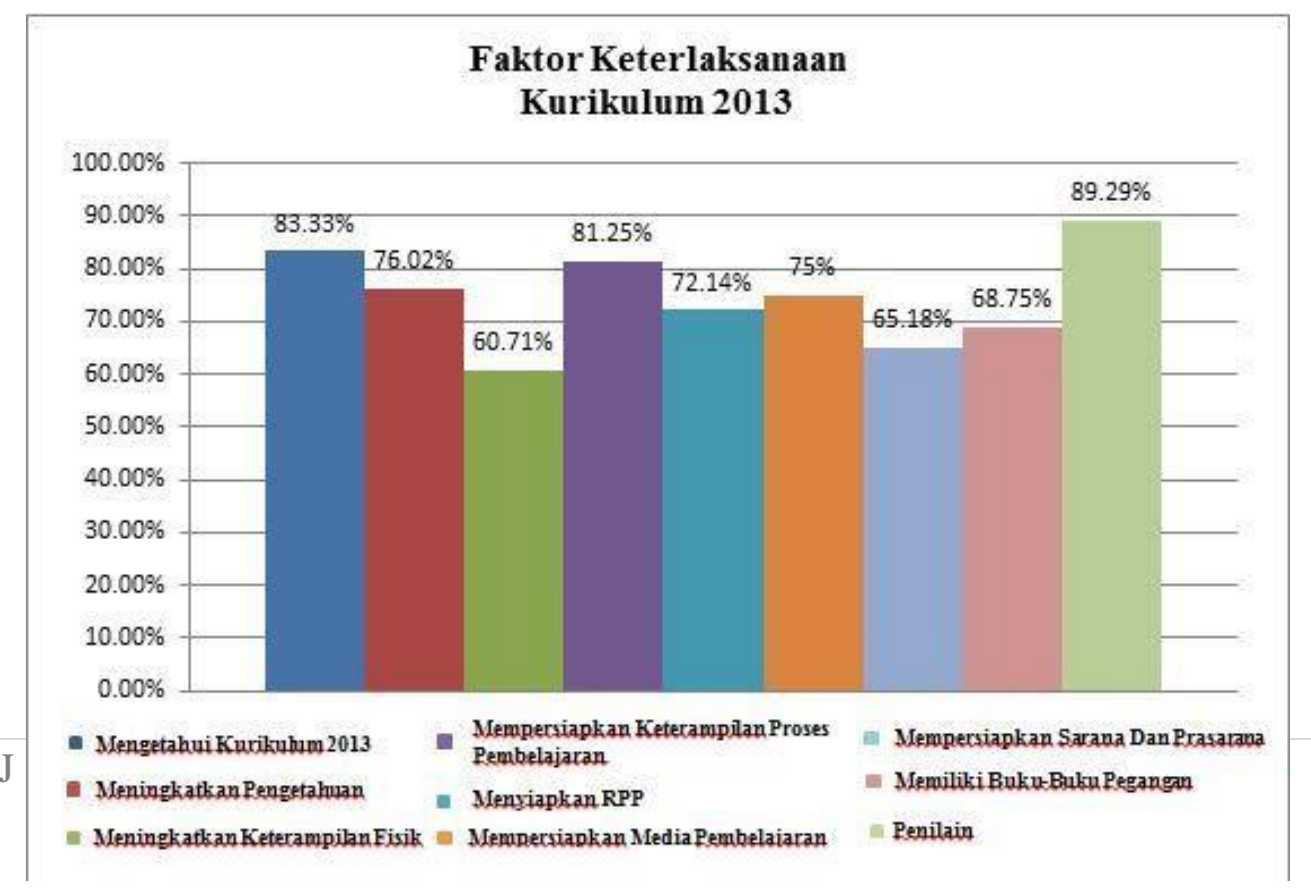




\section{Grafik 2. Persentase Faktor Keterlaksanaan Guru Penjesorkes Di Sekolah Dasar Se- Kecamatan Meliau Terhadap Kurikulum 2013.}

Dari grafik 2 diatas, dapat dilihat perbandingan bahwa faktor yang memiliki kategori mengetahui kurikulum 2013 adalah $83.33 \%$, meningkatkan pengetahuan $76.02 \%$, meningkatkan keterampilan fisik $60.71 \%$, mempersiapkan keterampilan proses pembelajaran $81.25 \%$, menyiapkan RPP 72.14\%, mempersiapkan media pembelajaran $75.00 \%$, mempersiapkan sarana dan prasarana $65.18 \%$, memiliki bukubuku pegangan $68.75 \%$ dan penilain $89.29 \%$.

\section{PEMBAHASAN}

Berdasarkan hasil penelitian yang telah dilakukan, dapat diketahui bahwa untuk keterlaksanaan guru penjasorkes terhadap kurikulum 2013 didapat rata-rata 14.3\% sangat baik. Itu artinya guru sudah memahami pelaksanaan kurikulum 2013, mulai dari pembuatan RPP sampai pelaksanaan dan evaluasi serta guru juga sudah meningkatkan pengetahuan, meningkatkan keterampilan fisik, mempersiapkan keterampilan proses pembelajaran, menyiapkan RPP, mempersiapkan media pembelajaran, mempersiapkan sarana dan prasarana, serta memiliki buku-buku pegangan dan penilaian.
Hal ini tentunya sangat berpengaruh baik terhadap seluruh elemen yang ada disekolah, terlebih bagi siswa karena mereka tidak akan bosan sebab gurunya memiliki kemampuan yang baik dan menguasai kopetensi yang ada. Menurut Mulyasa (2007: 69) mejelaskan bahwa guru memiliki andil yang sangat besar terhadap keberhasilan pembelajaran disekolah, guru sangat berperan dalam membantu perkembangan peserta didik untuk mewujudkan tujuan hidupnya secara optimal.

Pada penelitian sebelumnya, angka yang ditunjukan sebesar $82.60 \%$ pada kategori sangat baik (Yulvia Masruatin, 2015) tempat penelitian yang dilakukan oleh Yulvia Masruatin berada di SMP Islam Al Azhaar Desa kedung waru Kabupaten Tulungagung Kecamatan Purbalingga. Sedangkan peneliti berada di kecamatan Meliau Kabupaten Sanggau. Namun dengan jumlah sampel yang berbeda yaitu sebanyak 28 guru.

Selanjutnya untuk kategori baik didapat rata-rata $67.9 \%$ itu artinya guru telah mengimplementasikan kurikulum 2013 dengan baik berdasarkan fungsinya, namun guru belum sepenuhnya dapat 


\section{Jurnal Pendidikan Jasmani Kesehatan dan Rekreasi (Penjaskesrek)}

Volume 8, Nomor 1, Januari 2021

melaksanakan kurikulum 2013 adapun faktor yang mempengaruhi adalah belum lengkapnya sarana dan prasarana dalam pembelajaran seperti peralatan olahraga, hanya dapat buku pegangan dari pemerintah, tidak memiliki buku refrensi lain sehingga pelaksanaan belum dapat dilaksanakan secara maksimal. Sedangkan menurut Husnul Chotimah (dalam Asmani, 2012 : 20) guru adalah orang yang memfasilitasi alih ilmu pengetahuan dari sumber belajar kepada peserta didik.

Pada penelitian sebelumnya, yaitu penelitian yang dilakukan oleh Yulvia Masruatin (2015), hasil yang diperoleh sebesar $72.82 \%$ untuk kategori baik. tempat penelitian yang dilakukan oleh Yulvia Masruatin berada di SMP Islam Al Azhaar Desa kedung waru Kabupaten Tulungagung Kecamatan Purbalingga. Sedangkan peneliti berada di kecamatan Meliau Kabupaten Sanggau. Namun dengan jumlah sampel yang berbeda yaitu sebanyak 28 guru. Selanjutnya untuk kategori cukup didapat rata-rata $17.9 \%$, dimana guru hanya membuat RPP sesauai petunjuk, sehingga kebenaran dari RPP kadang masih banyak kesalahan, sehingga perlu adanya tindak lanjut dari kepala sekolah atau pengawas untuk selalu mengontrol dan memberi pembinaan demi kebaikan pembuatan RPP yang baik.

Keterbatasan media unrtuk pembelajaran juga masih bayak dirasakan oleh guru penjaskes lainnya seperti ketersediaan alat olahraga, keterbatasan jaringan seluler menyebabkan guru juga tidak bisa mecari referensi dari internet sehingga guru menggunakan buku pegangan hanya dari yang di dapat pemerintah saja. Pemahasan mengenai persiapan penilaian ini menjadi kendala yang cukup berari, dikarenakan dalam hal mengimplementasikan penilaian kurikulum 2013 guru diharapkan tidak hanya memiliki satu nilai tetapi tiga nilai, sehingga guru harus dituntut membuat instrumen penilain yang banyak.

Menurut Mulyasa (2012: 93) kunci sukses yang mendorong keberhasilan kurikulum 2013 antar lain: kepemimpinan kepala sekolah, kreativitas guru, aktifitas peserta didik, sosialisasi fasilitas dan sumber belajar, lingkungan yang kondusif akademik, dan partisipasi warga sekolah.

Motivasi guru dalam hal ini yaitu semangat dalam mengimplementasikan kurikulum 2013, dengan cara belajar sebaikbaiknya dan berusaha untuk mencari refrensi agar guru mampu memahami metode yang dapat diterapkan untuk mengimplementasikan kurikulum 2013. Dalam menerapkan kurikulum 2013 pada pembelajaran, tentunya harus memperhatikan prinsip dasarnya. Perlunya memperhatikan prinsip dasar k13 yang benar bertujuan untuk kesesuaian antara penerapan dan anjuran yanag ditetapkan. Adapun implementasi kurikulum 2013 
dilaksanakan atas dasar beberapaprinsip utama diantaranya:

1. Standar kopetensi lulusan diturunkan dari kebutuhan

2. Standar isi diturunkan dari standar kopetensi lulusan melalui kopetensi inti yang bebas mata pelajaran.

\section{SIMPULAN DAN SARAN}

\section{Simpulan}

Berdasarkan pada hasil penelitian yang telah peneliti lakukan untuk keterlaksanaan kurikulum 2013 mata pelajaran penjasorkes di Sekolah Dasar Sekecamatan Meliau berkategori sangat baik $14.3 \%$, kategori baik sebesar 67,9\%,dan kategori cukup sebesar 17,9\%. Berdasarkan hasil tersebut dapat disimpulkan keterlaksanaan guru PJOK di Sekolah Dasar Se-kecamatan Meliau terhadap kurikulum 2013 sebagian besar berkategori baik.

\section{Saran}

Saran yang dapat dijadikan acuan sebagai hasil dari kesimpulan penelitian yang ada adalah:

Bagi guru agar selalu mempersiapkan dengan baik pelaksanaan kurikulum 2013, dapat meningkatkan kualitas pembelajaran, profesionalisme dan melakukan inovasi dalam proses pembelajaran dengan melakukan upaya secara maksimal serta penambahan wawasan dengan berupaya mengenal kurikulum 2013 tanpa harus menunggu program sosialisasi dari pemerintah. Bagi sekolah agar menyiapkan sarana dan prasarana yang dibutuhan sehingga pelaksanaan kurikulum 2013 dapat berjalan dengan baik dan lancar. Bagi peneliti hendaknya memperbanyak populasi dan sample agar lebih luas sehingga keterlaksanaan guru PJOK terhadap kurikulum 2013 Sekolah Dasar dapat teridentifikasi dengan luas.

\section{DAFTAR RUJUKAN}

Arif dan Imam Setiadi. (2016). Psikologi Positif: Pendekatan saintifik menuju kebahagiaan. Jakarta: PT Gramedia Pustaka Umum

Arifin dan Jainal. (2012). Konsep dan Model Pengembangan Kurikulum. Bandung: PT Remaja Rosdakarya.

Dakir. (2010). Perencanaan dan Pengembangan Kurikulum. Jakarta: Rineka Cipta.

Hidayat, S. (2013). Pengembangan Kurikulum Baru. Bandung: PT Remaja Rosdakarya.

Maksum, A. (2012). Buku ajar matakuliah metodologi penelitian dalam olahraga. Surabaya : FIK Universitas Negeri Surabaya.

Mulyasa.

(2013).

Pengemb ang an dan Implementasi Kurikulum 2013. Bandung: PT. Remaja Rosdakarya. 
Jurnal Pendidikan Jasmani Kesehatan dan Rekreasi (Penjaskesrek) Volume 8, Nomor 1, Januari 2021

Nawawi, H. (2015). Metode Penelitian

Bidang Sosial. Yogyakarta: Gajah

Mada University Press.

Purwanto, N. (2012). Prinsip-Prinsip

dan Teknik Evaluasi Pengajaran.

Bandung: PT Remaja Rosdakarya.

Siregar, Syofian. (2013). Metode

Penelitian Kuantitatif. Jakarta:

Kencana.

Sugiyono. (2015). Metode Penelitian

Pendidikan. Bandung: Alfabeta.

Suryabrata. (2015).Metode

Penelitian. Jakarta: PT Raja

Grafindo Persada.

Tanzeh, A. dan Suyitno. (2006). Dasar-

Dasar Penelitian. Surabaya: Elkaf. 